\title{
The First Record for Peribatodes rhomboidaria (Lepidoptera, Geometridae, Ennominae) in Adana Province of Turkey and External and Genital Morphology of the Species
}

\author{
Erol ATAY ${ }^{1 *}$, Frantisek SLAMKA ${ }^{2}$ \\ ${ }^{1 *}$ Department of Biology, Faculty of Arts and Sciences, Mustafa Kemal University, Hatay, TURKEY \\ ${ }^{2}$ Racianska 61 SK-83102, Bratislava, SLOVAKIA f.slamka@nextra.sk
}

\begin{abstract}
This study was conducted in field and laboratory. Peribatodes rhomboidaria was caught in forested areas in Adana (Kozan) with light trap. In the field studies, totally 2 male and 4 female specimens were collected. Specimens were dissected in the laboratory and prepared male and female genitalia and wings slides. We described the external and male and female genital morphology of Peribatodes rhomboidaria in detail and also diagnostical morphological features. As a result of the study, Peribatodes rhomboidaria is a new record for Adana province.
\end{abstract}

Keywords: Adana, Lepidoptera, Peribatodes rhomboidaria, Geometridae.

\section{Türkiye Adana İlinde Peribatodes rhomboidaria (Lepidoptera, Geometridae, Ennominae)'nın İlk Kaydı ve Türün Dış ve Genital Morfolojisi}

$\ddot{\mathbf{O} z}$

$\mathrm{Bu}$ çalışma saha ve laboratuvar çalışmaları şeklinde gerçekleştirilmiştir. Peribatodes rhomboidaria, Adana Kozan ilçesinde ormanlık sahalarda ışık tuzağı kullanılarak yakalandı. Saha çalışmalarında toplam 2 erkek ve 4 dişi toplanmıştır. Örnekler laboratuvarda preparat yapımı için hazırlandı, erkek ve dişi bireylerin genital organları ile kanat preparatları yapıldı. Peribatodes rhomboidaria 'nın dış morfolojisi ve genital organları ayrıntılı olarak tanımlandı. Çalışma sonucu olarak Peribatodes rhomboidaria Adana ili için ilk kayıttır.

Anahtar Kelimeler: Adana, Lepidoptera, Peribatodes rhomboidaria, Geometridae. 


\section{Introduction}

Geometridae is a very large family with nine subfamilies, it has around 23000 species. The largest subfamilies of Geometridae, the Ennominae, with over 9700 described species (about $45 \%$ of all Geometridae), is well defined by a morphological character, the weakening or absence of the M2 in the hindwings (Viidalepp et al., 2007).

Peribatodes was established by Wehrli in 1943 with Peribatodes rhomboidaria Denis \& Schiffermüller, 1775 as the type species. It contains twelve described species worldwide (Karsholt and Razowski, 1996).

There are five species belonging to the genus Peribatodes in Turkey (Koçak and Kemal, 2009). The first attempt on the checklist of the Turkish moths were listed by Koçak and Kemal (2006, 2007). Totally 4604 moth species were listed together with their synonymous named and updated provincial distributions. Later, the authors (Koçak and Kemal, 2009) reported that the Turkey Lepidoptera fauna was 5128 species belonging to 76 families. In addition, a total of 692 lepidoptera species, 506 Heterocera and 186 Rhopalocera, belonging to the province of Adana were listed by the same authors. The species belonging to the genus Peribatodes is not found in Adana. Peribatodes rhomboidaria is new record for the the lepidoptera fauna of Adana.

\section{Materials and Methods}

\subsection{Field Studies}

Field studies were carried out in forested areas in Adana (Kozan) province in 2017. All the field works were done under suitable weather conditions (without precipitation and strong winds), and works started early in the morning and continued until sunset. Peribatodes rhomboidaria was caught in forested areas in Adana (Kozan) with light trap. In the field studies, totally 2 male and 4 female specimens were collected.

\subsection{Laboratory Studies}

Before they were losing body water, the collected specimens were sorted according to body sizes, and were needed with a number 0 insect needles that matched the size of the custom sized boards, strain and inhibition couples were strained in laboratory work. For the drying of the stretched specimens, they kept at room temperature for two weeks in a dark and dry place. Male and female genital organs were prepared for the identification of the species following morphological 
examinations and measurements on the male specimens. The needling of the butterflies, stretching of the wings and genital organ preparations were done accordingly the methods which defined in Atay's work (2006). The major taxonomic characters described. Important morphological organs of Peribatodes rhomboidaria were photographed and drawn. The specimens stored at the Biology Department of Mustafa Kemal University in Hatay.

\section{Results and Discussion}

\section{Genus Peribatodes Wehrli, 1943}

Syn: Peribatodes Wehrli, 1943 (Koçak and Kemal, 2009).

\section{Peribatodes rhomboidaria ([Denis \& Schiffermüller], 1775 (Geometridae, Ennominae)}

Syn: rhomboidaria [Denis \& Schiffermüller], 1775; inaequalis Goeze, 1781; gemmaria Brahm, 1791; ichnusaria Ghiliani, 1852; corsicaria Schawerda, 1931; seardabensis Wehrli, 1943 (Koçak and Kemal, 2009).

The distribution of Peribatodes rhomboidaria in Turkey: Amasya, Bolu, Bursa, Çanakkale, Edirne, Hatay, Mersin, İstanbul, Kars, Konya, Manisa, Kahramanmaraş, Muğla, Ordu, Sinop, Tekirdağ, Tokat, Trabzon, Van, Düzce (Koçak ve Kemal, 2009).

The distribution of Peribatodes rhomboidaria in the World: Denmark, Sweden, Finland, East Europe, Polland, Czech Republic, Slovakia, Germany, Netherlands, England, Irland, Belgium, Luxemburg, France, Spain, Portugal, Corsica, Sardinia, Sicily, Italy, Switzerland, Austria, Hungary, Romania, Bulgaria, Albania, Greece, Crete, Turkey (Karsholt and Razowski, 1996); Middle Europe, Span, Dalmatia, Greece (Hannemann, 1964).

\section{Material Examined}

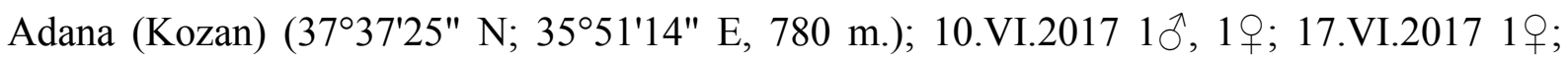
24.VI.2017 1q; 08.VII.2017 1ठ, 1 \% .

\section{Measurements of the Adults}

Body Length ठึ: 16-18 mm.;

Wingspan $\overbrace{}^{\Uparrow}: 36-38 \mathrm{~mm}$; ㅇ: 40-42 mm.

Male (Figure 1): On the head vertex and frons head whitish grey and also with small dark dots. Labial palps well developed, first and second segments long and slightly curved upwards and third segments very small and oblique; densely scaled, grayish brown, dorsally mixed with white; ventral completely dirty white. Antenna feathered, grayish brown on dorsal surface, beige and brown on ventral surface (in male plumose; in female filiform). Haustellum is well developed, quite long and 
reddish brown. Compound eyes are well developed, round, large and dark brown. On the head ocelli and chaetosemata absent.

Head is 1,53 times wider than it's length. In male antennae plumose (bipectinate) and medium length, densely covered with long cillia, it's length 0,5 times longer than forewing length; end of antenna $(2 \mathrm{~mm})$ without feathered. (Figures 2, 3).

On the thorax is whitish grey mixed yellowish brown scales; the ventral of thorax is dirty white. All of the legs are dirty white and also with small dark dots.

Forewings are long, wide and triangular, it's length 2 times longer than it's width. The ground color of the forewings is whitish grey and yellowish grey with brown dots. There are three blackish brown cross bands on the forewing. These bands in the postbasal, discal and postdiscal regions are thin and zigzag-shaped. The bands (second and third bands) in the discal and postdiscal regions come from separate points on the costa, but these bands unite at inner margin at one point. In addition, there are a few dark patterns in the apex and the outer margin. The ventral surface of the forewing is similar to the upper face, but it is more dull. Hindwings are quite broad and it's length 1,20 times longer than it's width. Veins of forewing and hindwing of Peribatodes rhomboidaria are as in Figure 4.

The male genital organ is as in Figures 5.

Uncus much short, distally pointed. Valvae long and large, it's length 4,25 times longer than it's width; its both sides covered long and thick spines. Valva with produced costal extension covered in spines. This costal extension of valva narrow, apex roughly level with that of valva. Medial protuberance rather pointed. The saccus is small. Aedeagus long, robust and rod shaped, it's length 8,2 times longer than it's width; vesica tubular with linear patch of corniti.

The female genital organ is as in Figures 6 and 7.

Ovipositor short. Papilla anales is sclerotized; with weak and sparse hairy. Apophyses posterior is longer than apophyses anteriores. Ostium sclerotized, small, narrow and cone-shaped. Ductus bursae sclerotized, very long and narrow; its length much greater than distance between ostium and apex of papillia anales. Corpus bursae broad and oval shaped, sclerotized. Signum thin and narrow, line-shaped.

In this study, we described the external and genital morphology of the male Peribatodes rhomboidaria. The important taxonomic characters belong to Peribatodes rhomboidaria were described in detail by comparasion of different parameters with each other. Each one of the external and genital taxonomic characters were measured with digital caliper and stereo microscope. This species is new record for the the lepidoptera fauna of Adana. 


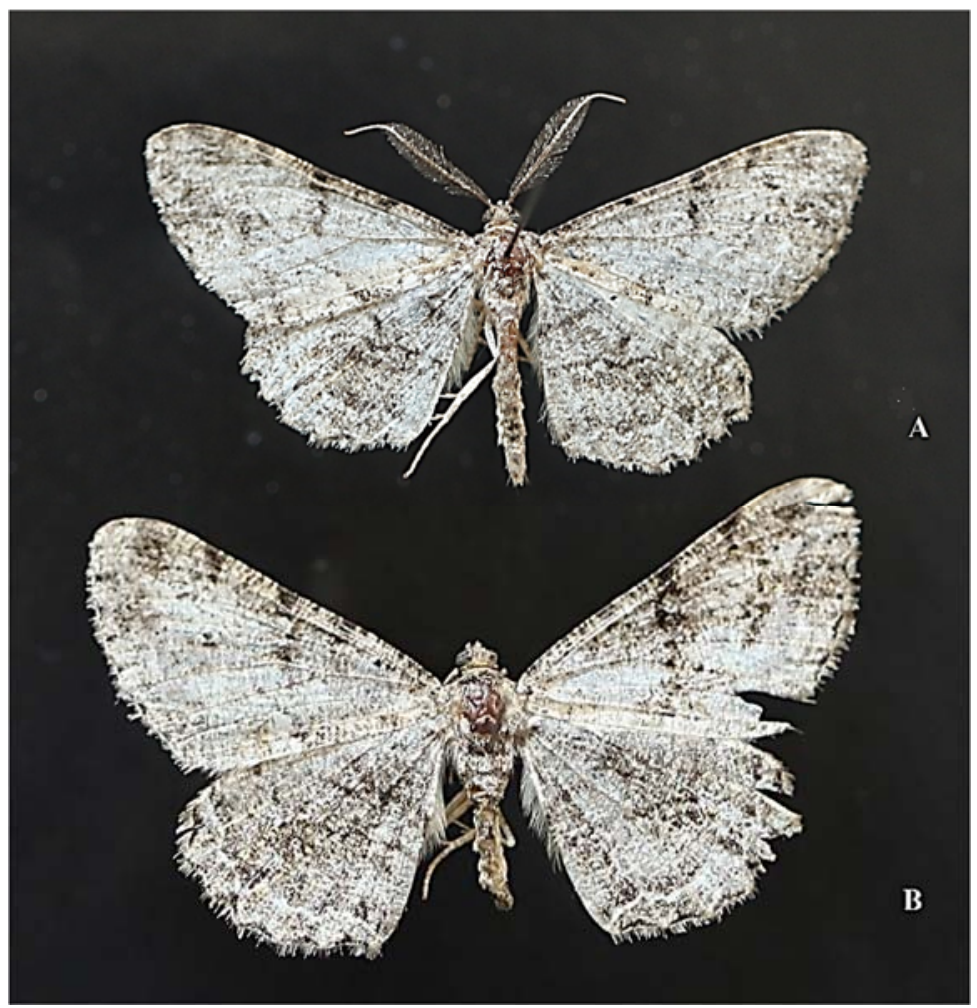

Figure 1. Adults of Peribatodes rhomboidaria (A Male, B Female).

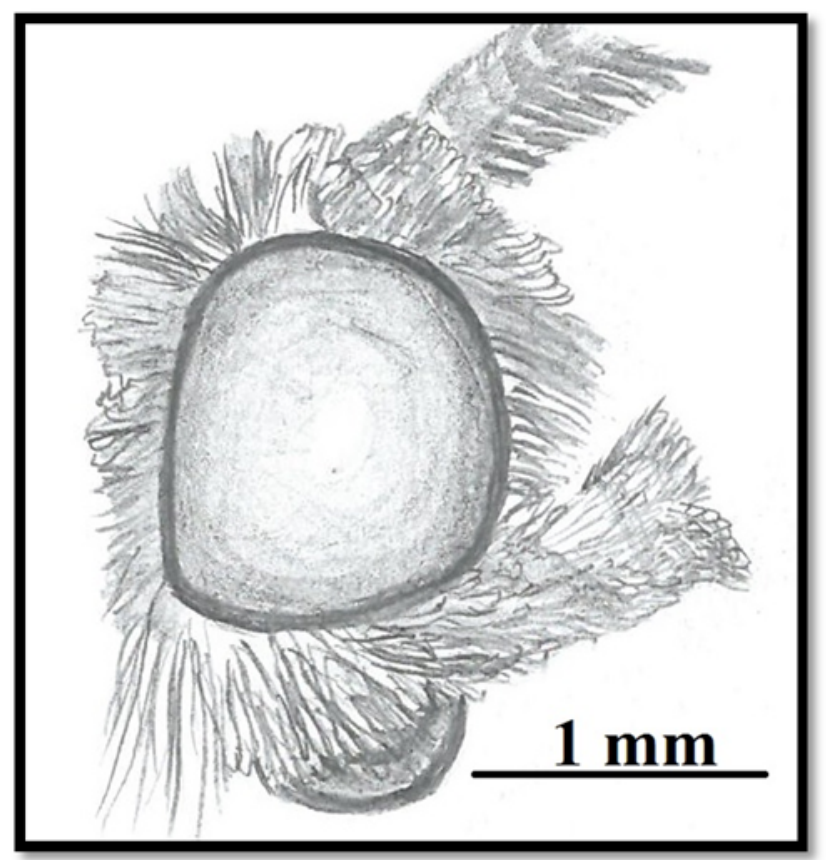

Figure 2. The head structure of Peribatodes rhomboidaria. 


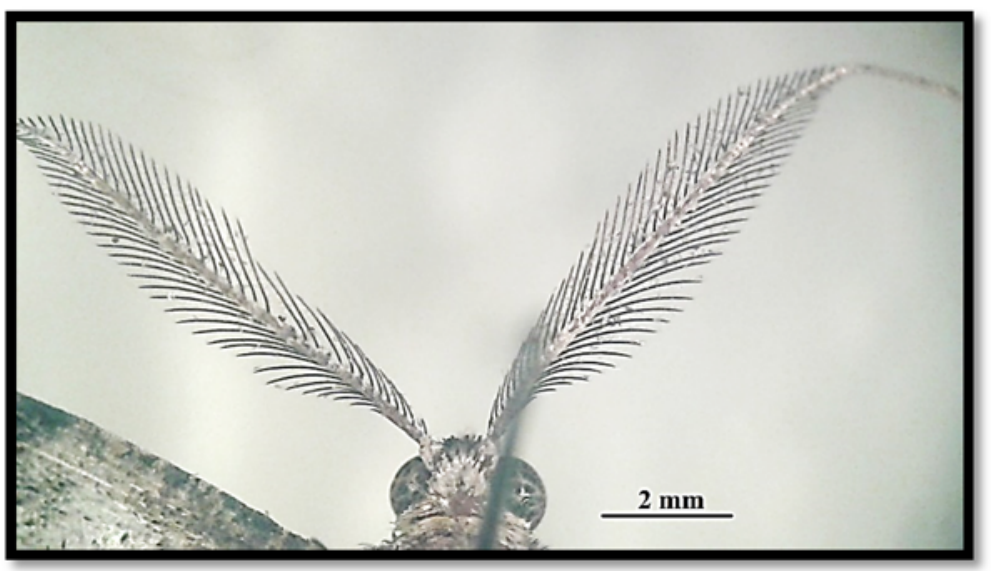

Figure 3. The Antennea of Peribatodes rhomboidaria.

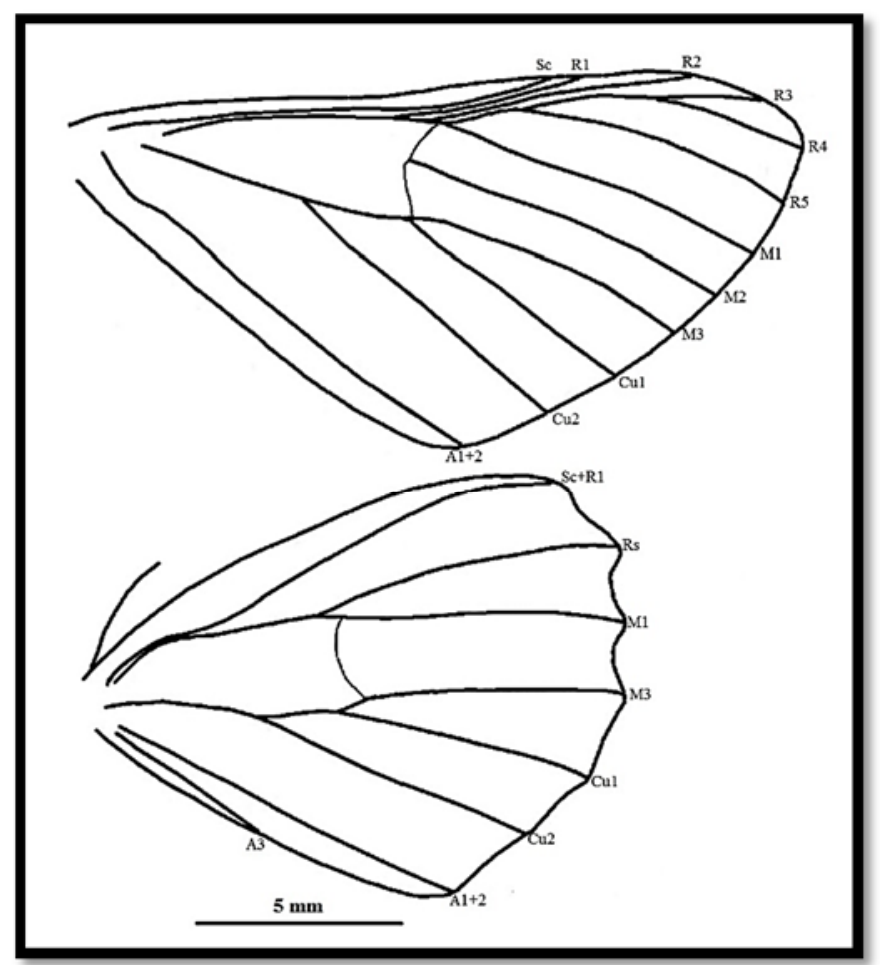

Figure 4. Veins of forewing and hindwing of Peribatodes rhomboidaria. 


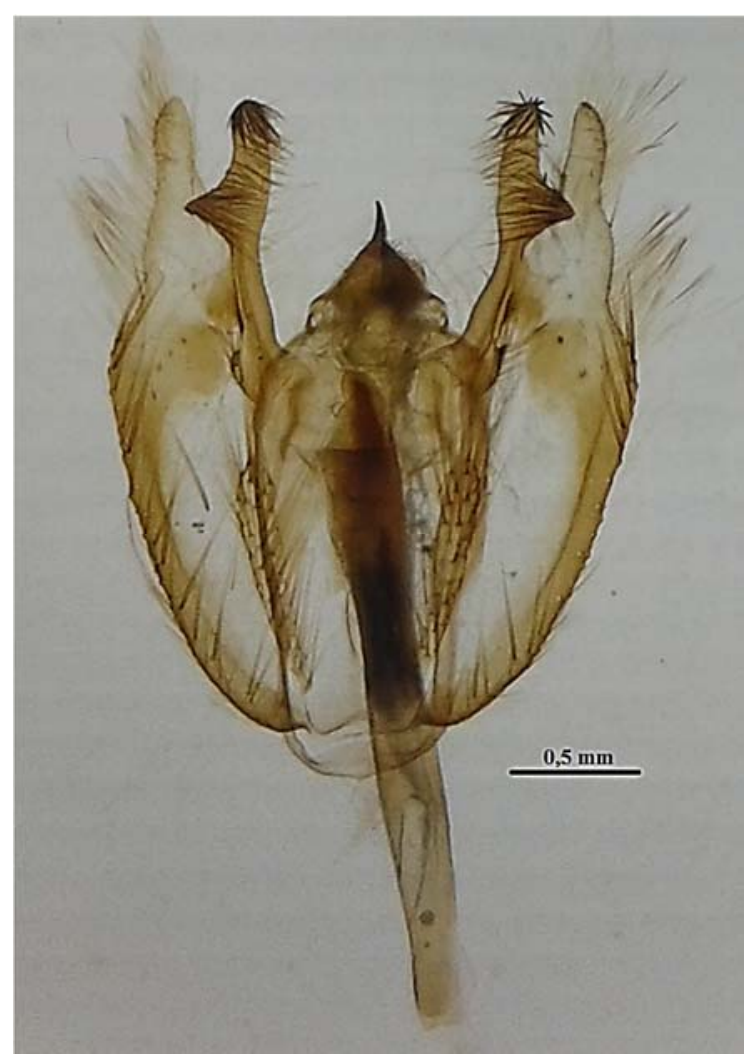

Figure 5. The Male Genitalia of Peribatodes rhomboidaria (Genitalia and Aedeagus).

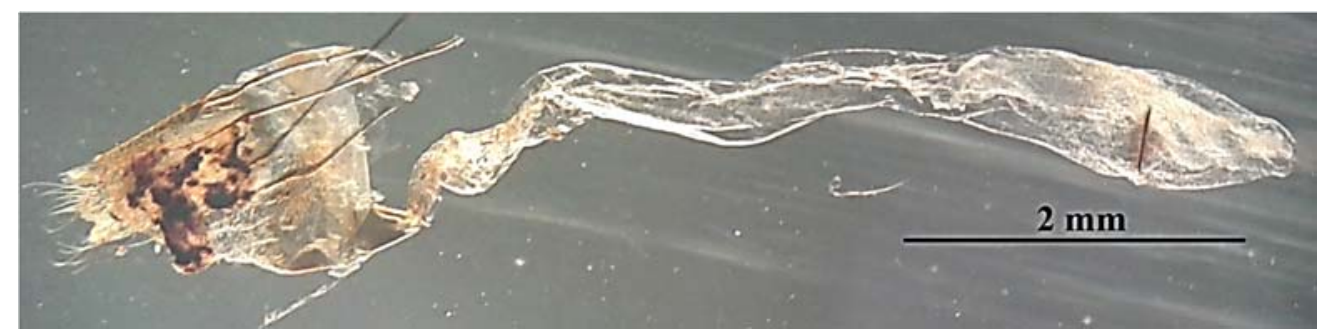

Figure 6. The Female Genitalia of Peribatodes rhomboidaria (General image).

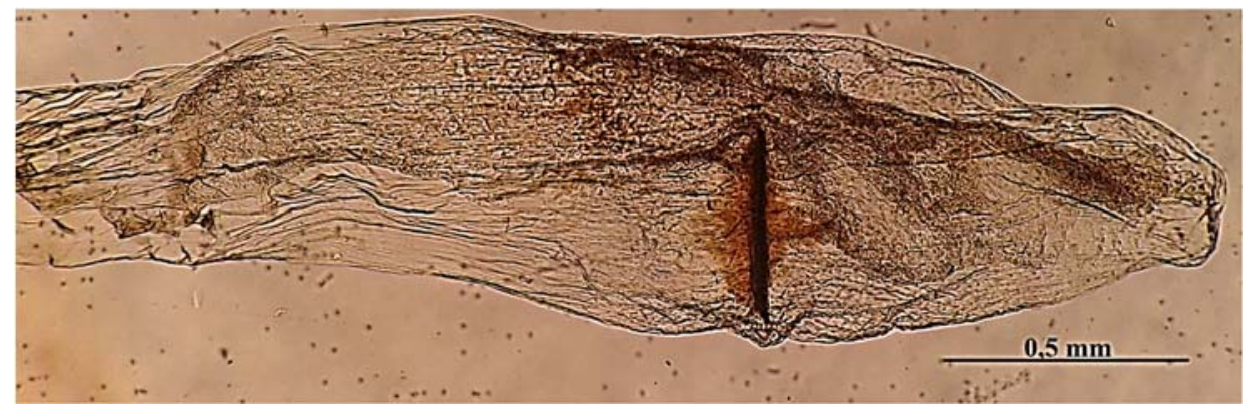

Figure 7. The Female Genitalia of Peribatodes rhomboidaria (Bursa Copulatrix and Signum). 


\section{References}

Atay, E. (2006). The Identity of Parapoynx affinialis (Guenee, 1854) (Lepidoptera, Crambidae, Nymphulinae) in Turkey. Journal of Entomology, 3(1), 76-81.

Hannemann H.J. (1964). Kleinschmetterlinge Oder Microlepidoptera. In Die Tierwelt Deutschlands und Der Angrenzenden Meeresteile. Veb Gustav Fischer Verlag, Germany, pp.403.

Koçak, A.Ö. and Kemal, M. (2006). Checklist of the Lepidoptera of Turkey. Centre for Entomological Studies Ankara, 1, 1-196.

Koçak A.Ö. and Kemal, M. (2007). Revised and annotated checklist of the Lepidoptera of Turkey. Centre for Entomological Studies Ankara, 8, 1-150.

Koçak A.Ö. and Kemal, M. (2009). Revised checklist of the Lepidoptera of Turkey. Centre for Entomological Studies Ankara, 17 1-150.

Karsholt, O. and Razowski J. (1996). The Lepidoptera of Europe A Distributional Checklist. Apollo Books. Denmark, pp. 380.

Viidalepp, J., Tammaru T., Snall N., Ruohomaki K. and Wahlberg N. (2007). Cleorodes Warrn, 1894 does not belonging in the Tribe Boarmiini (Lepidoptera: Geometridae). European Journal of Entomology, 104, 303-309. 